\title{
Predmarčni pesnik, politik in prevajalec Anastazij Grün kot mecen na Kranjskem
}

\author{
Tanja Žigon (Lublaň)
}

\begin{abstract}
Izvleček
V prispevku je predstavljeno manj znano prijateljstvo med predmarčnim pesnikom Anastazijem Grünom (18061876) in njegovim prvim biografom Petrom Pavlom pl. Radicsem (1836-1912). Radics je predmarčnega pesnika Anastazija Grüna spoznal konec petdesetih let 19. stoletja v Gradcu in mu v šestdesetih letih posvetil svojo razpravo o slavnem kranjskem deželnem glavarju Herbardu VIII. Turjaškem (1528-1575). Grün je z Radicsem prijateljeval in ga tudi finančno podpiral. To je Radicsu po eni strani omogočalo, da se je lahko nemoteno posvečal raziskovalnemu delu, po drugi pa se je s tem denarjem tudi preživljal. Na osnovi arhivskega gradiva je osvetljena ne le zgodba o njunem prijateljstvu, temveč tudi nekateri segmenti iz življenja in dela obeh osebnosti. Prispevek obenem ponuja tudi vpogled v kulturnozgodovinsko stvarnost na Kranjskem v drugi polovici 19. stoletja, ki so jo pogosto zaznamovali konflikti med kranjskim nemštvom in Slovenci.
\end{abstract}

\section{Ključne besede}

kulturna zgodovina; Kranjska; Anastazij Grün; Peter pl. Radics; nemško-slovenski stiki

\begin{abstract}
Anastasius Grün, Pre-March Revolution Poet, Politician, Translator, and Patron of the Arts in Carniola

The paper deals with the little researched friendship between Anastasius Grün (1806-1876) and his biographer Peter pl. Radics (1836-1912). Pavel von Radics met the pre-March Revolution poet Anastasius Grün at the end of the 1850's in Graz. In the 1860's, he dedicated to the latter his discussion about the renowned Carniolan governor Herbard VIII von Auersperg (1528-1575). Grün was friends with Radics and financially supported him. On the one hand, this enabled Radics to devote himself entirely to research work. On the other hand, the money enabled him to make a living. The paper is based on archival research and sheds a new light on their friendship as well as their personal and working lives. It also looks at the cultural and historical situation in the 19th-century Carniola, often marked by antagonisms between Slovenes and Germans in the region.
\end{abstract}

\section{Key words}

cultural history; Carniola; Anastasius Grün; Peter von Radics; German-Slovenian contacts

Prispevek je nastal v sklopu raziskovalnega programa Medkulturne literarnovedne študije, št. P6-0265, ki ga sofinancira Javna agencija za raziskovalno dejavnost Republike Slovenije iz državnega proračuna. 


\section{Uvod in predstavitev problema}

Zasebna pisma so od nekdaj pomemben kulturnozgodovinski vir, saj osvetljujejo odnose med dopisovalci, razkrivajo njihova svetovnonazorska prepričanja, intimne poglede, razmišljanja, pa tudi stiske in težave. ${ }^{1}$ Prav zato se pričujoča razprava opira na ohranjeno korespondenco med Antonom Aleksandrom grofom Auerspergom (1806-1876), ki ga morda bolje poznamo po njegovem psevdonimu Anastazij Grün, ${ }^{2}$ ter njegovim prvim biografom, prijateljem in kranjskim polihistorjem Petrom pl. Radicsem (1836-1912). Uvodoma je podan pregled dosedanjih raziskav o Auerspergu in orisan njegov odnos do Kranjske. Študija primera, ki sledi, podrobneje analizira in osvetljuje Auerspergov odnos do ustvarjalcev na Kranjskem, predvsem njegovo nesebično pripravljenost, da priskoči na pomoč literatom, ki so s svojim pisanjem in ustvarjanjem pogosto komajda zaslužili dovolj, da bi preživeli. Anastazij Grün pa, kot izhaja iz pisem, mladim talentom pomoči ni odklonil, temveč je poskušal pomagati, kjer je le lahko.

Prispevek temelji na analizi tridesetih Radicsevih pisem Grünu. V Grünovi zapuščini v Gradcu je shranjenih sedemnajst Radicsevih pisem, ${ }^{3}$ v arhivu rodbine Auersperg na Dunaju $^{4}$ pa še trinajst pisem. Žal niti v Radicsevi ljubljanski zapuščini v Narodnem muzeju Slovenije ter v Arhivu Slovenije niti v zapuščini v zasebni lasti v Zagrebu ni ohranjenih Grünovih pisem Radicsu. ${ }^{5}$ O slednjih izvemo le posredno, saj je Radics v svojih delih pogosto omenjal Grünova pisma, deset pisem, napisanih med 30. oktobrom 1860 ter 21. aprilom 1876, pa je celo v celoti objavil in deloma skopo komentiral v monografiji Anastasius Grün. Verschollenes und Vergilbtes aus dessen Leben und Wirken. ${ }^{6}$

1 KRAUSSE, Erika (ur.): Der Brief als wissenschaftshistorische Quelle. Berlin: VWB-Verlag, 2005, s. 1-28.

2 Priložnostno je poleg psevdonima Anastazij Grün uporabljal še psevdonim Anton Alexander Bergenau (prim. SIENERTH, Stefan: Anastasius-Grün-Rezeption und der Standort der siebenbürgisch-deutschen Lyrik in der ersten Hälfte des 19. Jahrhunderts. In: JANKO, Anton - SCHWOB, Anton (ur.): Anastasius Grün und die politische Dichtung des Vormärz. München: Südostdeutsches Kulturwerk, 1995, s. 123-136, tu s. 125).

3 Karlova in Francova univerza v Gradcu, Oddelek za germanistiko (v nadaljevanju KFU), zapuščina Anastazija Grüna.

4 Hišni, dvorni in državni arhiv na Duanju (Wiener Haus-, Hof- und Staatsarchiv, v nadaljevanju HHStA), Fürstlich Auerspergsches Archiv, razdelek XXI (Thurn am Hart), C. 49, karton 30.

5 V Narodnem muzeju Slovenije (v nadaljevanju NMS) je shranjen osrednji del Radicseve zapuščine (več o tem ŽIGON, Tanja: Zgodovinski spomin Kranjske. Življenje in delo Petra Pavla pl. Radicsa (1836-1912). Ljubljana: ZZDS, 2009. Arhiv Republike Slovenije hrani 14 fasciklov gradiva Petra Pavla pl. Radicsa (AS 984), v Narodni in univerzitetni knjižnici v Ljubljani pa v posameznih zapuščinah hranijo nekatera Radicseva pisma. Med njimi ni pisem, ki bi bila povezana z Grünom. V Zagrebu hrani ostalino družine Radicseva pravnukinja, gospa Dagmar Najberger.

6 RADICS, Peter von: Anastasius Grün. Verschollenes und Vergilbtes aus dessen Leben und Wirken. Leipzig: Verlag von Hermann Foltz, 1879, s. 193-200. 


\section{Dosedanje raziskave}

Prvo obsežnejšo študijo, posvečeno Antonu Aleksandru grofu Auerspergu, ki torej prihaja iz znane rodbine Turjaških, je leta 1970 napisala Breda Požar, ${ }^{7}$ v osemdesetih letih se je s to tematiko ukvarjal Vasilij Melik, ${ }^{8} \mathrm{v}$ zadnjih dveh desetletjih pa je spričo dvestoletnice Auerspergovega rojstva kakor tudi spričo stotridesete obletnice njegove smrti, izšlo nekaj znanstvenih publikacij o njem. Potem ko je leta 1994 v Ljubljani potekala mednarodna in interdisciplinarna konferenca z naslovom »Anastazij Grün in politična literatura v predmarčnem času « in so bili njeni znanstveni izsledki leto pozneje objavljeni v znanstveni monografiji, ${ }^{9}$ sta dobro desetletje pozneje izšli še dve obsežni znanstveni publikaciji, ki se posvečata politiku, a tudi umetniško nadarjenemu Turjačanu, ter obravnavata njegovo življenje in delo. Leta 2009 je v Ljubljani izšla prva interdisciplinarna publikacija o Grünu v slovenskem jeziku, ${ }^{10}$ leta 2010 pa je Dietmar Scharmitzer ${ }^{11}$ pri založbi Böhlau izdal doslej najobsežnejšo in poglobljeno monografijo o predmarčnem pesniku, ki je kasneje stopil tudi na politični oder ter se preizkusil še kot dramatik in prevajalec. Obe omenjeni deli se posvečata življenjski in ustvarjalni poti Anastazija Grüna, ki mu je bilo plemstvo položeno v zibelko, ${ }^{12}$ a je bil po svojih nazorih bližje meščanstvu in se je v orbito predmarčnih umetnikov zavihtel z izdajo zbirke pesmi Sprehodi dunajskega pesnika (Spaziergänge eines Wiener Poeten), na svetlo dane leta 1831 v Hamburgu. Pesmi, v katerih je Auersperg prisegal na tedaj še nevidno moč in veličino monarhije, so hitro našle pot med bralce po monarhiji in zbirka se je nezadržno širila med ljudmi ter postala celo vzor za sodobne pesnike Mlade Nemčije (nem. Junges Deutschland). Politika je ukrepala in knjižico prepovedala, konec tridesetih let 19. stoletja pa uvedla preiskavo, da bi odkrila avtorja, ki se skriva za psevdonimom Anastasius Grün in je s svojimi liberalnimi nazori postal eden največjih nasprotnikov Metternichovega režima. ${ }^{13}$ Mladi Auersperg se je medtem poročil s hčerko grofa Ignaza von Attemsa (1774-1861), štajerskega deželnega glavarja, in ko je Metternich končno prišel na sled anonimnemu pesniku z njim ni mogel obračunati kot bi sicer z nasprotnikom, ki ne bi imel vplivnega sorodstva. Zato mu je v privatni avdienci, ki ji je skrit pred Auerspergovimi očmi prisostvoval tudi predsednik dunajskega dvornega policijskega in cenzurnega urada Joseph von Sedlnitzky

7 POŽAR, Breda: Anastasius Grün in Slovenci. Maribor: Založba Obzorja, 1970.

8 MELIK, Vasilij: A. A. Auersperg in slovenski narod. Zgodovinski časopis 41, 1987, št. 2, s. 285-295.

9 JANKO, Anton - SCHWOB, Anton (ur.): Anastasius Grün und die politische Dichtung des Vormärz. München: Südostdeutsches Kulturwerk, 1995.

10 MILADINOVIĆ ZALAZNIK, Mira - GRANDA, Stane (ur.): Anton Aleksander grof Auersperg - Anastazij Grün. Ljubljana: Nova revija, 2009.

11 SCHARMITZER, Dietmar: Anastasius Grün (1806-1876). Leben und Werk. Wien/Köln/Weimar: Böhlau, 2010.

12 Več o Auerspergih prim. PREINFALK, Miha: Auerspergi. Po sledeh mogočnega tura. Ljubljana: Zgodovinski inštitut Milka Kosa ZRC SAZU, 2005.

13 O političnih idejah v Grünovih literarnih delih prim. JAVOR BRIŠKI, Marija: The uses of the past: Anastasius Grün's political ideas in the field of fiction. XLinguae 8, 2015, št. 3, s. 31-40. 
(1778-1855), položil na srce, naj preneha pesniti ali pa zapusti monarhijo. Anastazij Grün je že iz kljubovanja, kot je zapisal v pismu svojemu založniku Weidmannu, ostal. ${ }^{14}$

Grüna so že kmalu po njegovih prvih literarnih uspehih zasenčili njegovi sodobniki. V nemškem prostoru je bil to Nikolaus Lenau (1802-1850), ${ }^{15}$ v slovenskem pa France Prešeren (1800-1849), ${ }^{16}$ danes znan kot avtor slovenske nacionalne himne in največji slovenski pesnik, svojčas pa je sodil v krog Grünovih prijateljev. Njun odnos, tako na osebnem kot tudi na literarnem področju, so v zadnjem desetletju raziskovali predvsem Mira Miladinović Zalaznik, ${ }^{17}$ Igor Grdina ${ }^{18}$ in Matjaž Birk. ${ }^{19}$ Auersperg in Prešeren sta bila skorajda sovrstnika: Grün je bil šest let mlajši od Prešerna, zato seveda še ni mogel stopiti v ospredje kot njegov mecen. Vseeno pa njuno prijateljstvo govori o Auerspergovi naklonjenosti kranjskim rojakom. Prešeren in Grün sta se spoznala v dvajsetih letih 19. stoletja, ko je bil Grün gojenec zasebnega konservativnega zavoda (Klinkowströmische Erziehungsanstalt), kamor ga je kot »težavnega« in težko vzgojljivega dijaka poslal pobožni očim, Prešeren pa, ki je tedaj prav tako študiral pravo na Dunaju in je bil v Klinkowströmovem zavodu Grünov zasebni učitelj, je pridobil zaupanje mlajšega rojaka in mu dovolil prebiranje prepovedanih avtorjev, med njimi Homerja, Evripida, Sofokla, Boccaccia, Ovidija itd., kar ga je pozneje stalo službe v Zavodu in s tem še kako potrebnega zaslužka. ${ }^{20}$ Stiki med obema Kranjcema pa tudi kasneje niso zamrli. Srečevala sta se v Ljubljani ali na Grünovi posesti Šrajbarski turn (nem. Thurn am Hart) v vasi Leskovec pri Krškem, kjer se jima je navadno pridružil še Prešernov prijatelj Andrej Smole (1800-1840), tudi sam zbiralec in zapisovalec ljudskih pesmi. ${ }^{21}$ Spomin na Grüna nam je Prešeren zapustil, ko je v času svojega bivanja v Celovcu v letih 1823 in 1824 prepesnil Auerspergovo pesem Venezianer Trias in ji dal naslov Tri želje Anstazija Zelenca, pri čemer ne moremo spregledati, da je slovenski prevod Zelenec (torej Grün) malce slabšalen in je Prešeren z njim opozoril na nezrelost nemškega pesnika. ${ }^{22}$ Prešernova smrt 8. 2. 1849 je Grüna pretresla, morda toliko bolj, ker je veliki pesnik umrl na isti dan kot njegov oče leta 1818. Prešerna se je Grün spomnil v žalostinki Nachruf an Preshérn, v kateri je Prešernove pesmi umestil v nravstvene in nadnacionalne kategorije

14 SCHARMITZER, Dietmar: Anastasius Grün. Op. cit., s. 161-163.

15 Več o tem MÁDL, Antal: Anastasius Grün und Nikolaus Lenau. Eine Dichterfreundschaft. In: JANKO, Anton - SCHWOB, Anton: Anastasius Grün und die politische Dichtung. Op. cit., s. 55-80.

16 Prvi je o njunem prijateljstvu pisal RADICS, Peter von: Anastasius Grün und seine Heimath. Festschrift zum 70jährigen Jubiläum des Dichters (11. April 1876). Stuttgart: Verlag der J. G. Cotta'schen Buchhandlung, 1876; isti: Anastasius Grüns Lehrer und Freund der slovenische Dichter France Preschiren als deutscher Poet. Leipzig: J. H. Webel, 1882.

17 MILADINOVIĆ ZALAZNIK, Mira: Deutsch-slowenische literarische Wechselbeziehungen. Leopold Kordesch und seine Zeit. Ljubljana: ZZFF, Oddelek za germanistiko s skandinavistiko in nederlandistiko, 2008.

18 GRDINA, Igor: Anastazij Zelenec ter slovenska in nemška (literarno)zgodovinska stvarnost. In: GRDINA, Igor (ur.): Med dolžnostjo spomina in razkošjem pozabe: kulturnozgodovinske študije. Ljubljana: Založba ZRC, ZRC SAZU, 2006, s. 241-256.

19 BIRK, Matjaž: Österreichisch-slowenischer Kulturtransfer am Beispiel von Anastasius Grün und France Prešeren. Modern Austrian Literature 41, 2008, št. 2, s. 1-18.

20 SCHARMITZER, Dietmar: Anastasius Grün. Op. cit., s. 69.

21 MILADINOVIĆ ZALAZNIK, Mira: Deutsch-slowenische literarische Wechselbeziehungen. Op. cit., s. 152-153.

22 Ibidem, s. 153. 
ter poudaril tudi njihov nacionalni ton. Pesem je nameraval objaviti v dunajskem časopisu Ostdeutsche Post, vendar pa njena ideološka vsebina ni ušla budnemu očesu cenzure, zato so jo natisnili šele leta 1859 v Vodnikovem albumu v Ljubljani. ${ }^{23}$

\section{Auersperg in njegov odnos do Kranjske in kranjskih ustvarjalcev}

Neglede na opisano prijateljstvo med Auerspergom in Prešernom pa je potrebno povedati, da je bil Grünov odnos do rojakov in do Kranjske, ${ }^{24}$ dežele, ki jo je Johann Gottfried Seume (1763-1810) označil za »zadnji košček nemške domovine« (»das letzte Zipfelchen unsers deutschen Vaterlandes «), ${ }^{25}$ precej ambivalenten. V kolektivni spomin na Kranjskem se je grof Anton Aleksander Auersperg zapisal kot gospodarstvenik, ki je podedoval očetovo zadolženo gospostvo Šrajbarski turn, gospodarske sanacije posesti pa se je lotil tako, da je od kmetov izterjeval podložniške obveznosti in jih brezobzirno izžemal do te mere, da so poskušali organizirati celo kmečki upor. ${ }^{26}$ Dogodki so odmevali celo v dunajskem časopisu Wiener Kirchenzeitung in si prislužili oznako »kmečka afera« (»Bauernaffäre «). ${ }^{27}$ Pisatelj Janez Trdina (1830-1905) je imel Grüna za enega najbolj krutih zemljiških gospodov na Kranjskem v zadnjih desetletjih fevdalizma in je o njem zapisal: »Brezdušnega zatiralca slovenskih kmetov se noben rodoljub ne more spomniti drugače kakor $\mathrm{z}$ gnusom in zaničevanjem. $«^{28}$ Vseeno pa mu glede tega včasih delamo krivico, saj je prav Grün sestavil posebno spomenico, naslovljeno na kranjske deželne stanove, ki je dokazovala davčno preobremenitev tistih delov dežele, ki so bili najbolj revni, torej tudi Dolenjske. V revizijskem postopku je država preverila izračunavanje davčne osnove, kar je pokazalo, da so bile pritožbe kmetov pogosto utemeljene. ${ }^{29}$ Grünov ugled v očeh rojakov se je tako nemudoma povečal. Prav tako je grof še v revolucionarnem letu 1848 v poslanici »An meine slovenischen Brüder « (»Mojim slovenskim bratom «), ${ }^{30}$ izrazil naklonjenost kulturnemu razvoju Slovencev ter skušal rojake prepričati, da se morajo zavzemati za politične pravice v frankfurtskem parlamentu. Kranjski literat, publicist in urednik Leopold Kordesch (1808-1879) je tedaj v nemškem Ilirskem listu (Illyrisches

23 BIRK, Matjaž: Österreichisch-slowenischer Kulturtransfer. Op. cit., s. 5.

24 Več o tem MELIK, Vasilij: Alexander graf Auersperg und die Slowenen. In: JANKO, Anton - SCHWOB, Anton: Anastasius Grün und die politische Dichtung. Op. cit., s. 93-108.

25 SEUME, Gottfried: Spaziergang nach Syrakus im Jahre 1802. München: DTV, 1985, s. 36.

26 GRANDA, Stane: Anastazij Grün - gospodarstvenik. In: MILADINOVIČ ZALAZNIK, Mira - GRANDA, Stane: Anton Aleksander grof Auersperg. Op. cit., s. 31-45, tu s. 35.

27 BIRK, Matjaž: Österreichisch-slowenischer Kulturtransfer. Op. cit., s. 3.

28 TRDINA, Janez: Avtobigrafska pisma (ur. Fr. Derganc). Ljubljanski zvon 26, 1906, št. 2, s. 77-82, tu s. 81.

29 GRANDA, Stane: Anastazij Grün - gospodarstvenik. Op. cit., s. 31-45.

30 Besedilo je v nemščini objavil v posebni prilogi časnika Laibacher Zeitung 29. aprila 1848 (Besondere Beilage III. zur Laibacher Zeitung, št. 52, nepag.). Več o tem MILADINOVIĆ ZALAZNIK, Mira: Anastasius Grün und das Vereinte Slowenien. Germanistische Mitteilungen 67, 2008, s. 51-63. 
Blatt), literarno-kulturni prilogi dnevnika Laibacher Zeitung, objavil pesem Märzveilchen, ki jo je posvetil Grünu. ${ }^{31}$

Slovencem se je Grün nadalje približal tudi s svojim zanimanjem za slovensko ljudsko pesem. Posamezni prevodi pesmi so najprej izhajali v revijalnem tisku, na primer v Schwabovem in Camissovem literarnem časopisu Deutscher Musenalmanach v Leipzigu in v Hormayrjevem časopisu Taschenbuch für vaterländische Geschichte na Dunaju, ${ }^{32}$ zbirka Volkslieder aus Krain (Kranjske ljudske pesmi) pa je izšla leta 1850 v Leipzigu ter prvi ponatis doživela leta 1987 pri založbi ddr. Rudolfa Trofenika v Münchnu. ${ }^{33}$ Bleiweisov časopis Kmetijske in rokodelske novice je Grünove prevode pohvalil že 7. avgusta 1844, torej še preden so pesmi zares izšle v samostojni zbirki. Grün se na pozitivno recepcijo ni odzval in jo je doživljal bolj kot »samoumeven poklon inferiornih bitij «. ${ }^{34}$ Čeprav je znano, da je Auerspergov oče, Aleksander grof Auersperg (1770-1818), že leta 1815 javno izkazal svoj domovinski interes, ko je ob proslavi Napoleonovega padca na svoji ljubljanski palači izobesil napis »Ljubimo cesarja dobriga Slovenci «, ${ }^{35}$ je njegov sin Anastazij Grün leto dni po revolucionarnih dogodkih, torej 1849, pisal prijatelju Eduardu Bauernfeldu (1802-1890), da se po njegovih žilah sicer pretaka tudi slovanska kri, koliko je te krvi, pa noče kemično analizirati, ve pa, da je njegovo srce nemško in njegova srčna domovina Nemčija. ${ }^{36}$ Dokončno se je Slovencem zameril v času ustavne dobe, ko je bil v letih od 1861 do 1867 poslanec kranjskega deželnega zbora. Ko se je februarja 1866 v deželnem zboru razvnela razprava o vpeljavi slovenskega učnega jezika na kranjske gimnazije, je Grün razpravljal o slovenščini kot jeziku ljudstva in nemščini kot omikanem, kulturnem jeziku $^{37}$ in s seboj prinesel učbenika za prirodopis rastlinstva in živalstva. V razpravi je poudaril, da mora nesrečni slovenski dijak ob tem priti do enakega sklepa kot grški filozof: Omnia mea mecum porto (Vse, kar je moje, nosim s seboj). ${ }^{38} \mathrm{~V}$ slovenskem in nemškem

31 KORDESCH, Leopold: Märzveilchen. Illyrisches Blatt. Zeitschrift für Vaterland, Kunst, Wissenschaft und geselliges Leben 20, 1848, št. 27, s. 105 .

32 POŽAR, Breda: Anastasius Grün in Slovenci. Op. cit., s. 82. Avtorica v svoji knjigi analizira Grünove prevode in jih postavlja v kulturnozgodovinski kontekst (s. 81-262). O prevodih prim tudi SERNETZ, Peter: Anastasius Grün als Übersetzer slovenischer Volkslieder. Doktorska disertacija. Graz: Universität Graz, 1932; JANKO, Anton: Anastasius Grün als Übersetzer von Volksliedern. In: KONDRIČ HORVAT, Vesna (ur.): Nekoč se bodo vendarle morale sesuti okostenele pregrade med ljudstvi: spominski zbornik ob sedemdesetletnici Draga Graha. Ljubljana: ZZFF in Oddelek za germanistiko z nederlandistiko in skandinavistiko, 2007, s. 56-68.

33 MILADINOVIĆ ZALAZNIK, Mira: Auersperg, Marija Anton Aleksander, grof (1806-1876). In: ŠTRBENC SVETINA, Barbara et al. (ur.): Slovenska biografija. Ljubljana: SAZU in ZRC SAZU, 2013 (dostopno na: http://www.slovenska-biografija.si/oseba/sbi131820/\#novi-slovenski-biografski-leksikon; dostop 10. september 2019).

34 GRDINA, Igor: Anton Aleksander Auersperg ter slovenska in nemška (literarno)zgodovinska stvarnost. In: MILADINOVIČ ZALAZNIK, Mira - GRANDA, Stane: Anton Aleksander grof Auersperg. Op. cit., s. 47-65, tu s. 65 .

35 Ibidem, s. 64.

36 POŽAR, Breda: Anastasius Grün in Slovenci. Op. cit., s. 18.

37 CASTLE, Eduard (ur.): Anastasius Grüns Werke in sechs Teilen. Berlin - Leipzig - Wien - Stuttgart: Deutsches Verlagshaus Bong \& Co., 1909, VI. del, s. 243.

38 MELIK, Vasilij: Anton Alexander Graf Auersperg und die Slowenen. In: JANKO, Anton - SCHWOB, Anton: Anastasius Grün und die politische Dichtung. Op. cit., s. 93-108, tu s. 101. 
tisku se je kmalu razširila anekdota, da je Grün vso strokovno literaturo, ki obstaja v slovenskem jeziku, prinesel v deželni zbor v žepnem robcu, kar kaže na Grünovo resolutno zavračanje slovenskih emancipacijskih teženj na področju kulture. ${ }^{39}$

Po drugi strani pa moramo Anastaziju Grünu priznati, da je bil do kranjskih rojakov razumevajoč ter je pogosto ne le z besedami, temveč tudi z dejanji podpiral njihovo delo. Kot razberemo iz ohranjene korespondence, je finančno pomagal Leopoldu Kordeschu, ${ }^{40}$ bil je mecen izjemno nadarjenega slovenskega lirika in prevajalca Josipa Cimpermana (1847-1893), ${ }^{41}$ ki mu usoda ni bila mila in je bil priklenjen na invalidski voziček, posebno prijateljstvo pa se je spletlo med Grünom in skoraj trideset let mlajšim kranjskim rojakom, Petrom pl. Radicsem, ki se je rodil v Postojni in se je v literarno zgodovino zapisal kot prvi Grünov biograf. V nadaljevanju je najprej na kratko predstavljeno, kdo je bil Radics, sledi pa podrobnejša analiza korespondence z Grünom.

\section{Kdo je bil Peter pl. Radics?}

Peter pl. Radics se je v slovensko kulturno zgodovino zapisal kot vsestranski raziskovalec, zgodovinar, germanist, teatrolog in publicist, ki je za časa svojega življenja objavil več kot 550 člankov in razprav ter 76 samostojnih monografskih publikacij ${ }^{42} \mathrm{z}$ najrazličnejših področij, kot so kulturna zgodovina, geografija, etnografija, literatura, gledališče, gospodarstvo, diplomacija, zaradi česar ga lahko imenujemo ne le »kranjski historiograf «, ${ }^{43}$ temveč kar kranjski polihistor. Med njegova najpomembnejša dela sodijo razprave in monografije o gledališču na Slovenskem ter biografija o polihistorju Janezu Vajkardu Valvasorju (1641-1693), ki velja sploh za prvo znanstveno monografijo na Slovenskem in za katero je Radics leta 1910 s podelitvijo naziva cesarski svetnik dobil tudi visoko javno priznanje za svoje delo. Radics se nacionalno ni opredeljeval. Po rodu ni bil Slovenec: mati je prihajala s Spodnjeavstrijskega, oče pa je bil madžarski plemič. Radics je tako nihal je med slovenstvom in nemštvom, vsekakor pa je njegovo življenje in delo zaznamovala ljubezen do Kranjske domovine. ${ }^{44}$ Svoj priimek je občasno zapisoval kot Radič, večinoma pa je uporabljal madžarsko obliko Radics. Kot je ugotovil Miha Preinfalk, ni bil v sorodu z ljubljanskimi Radiči, vsekakor pa je tako kot tudi njegov oče Peter von Radits

39 Leta 1871 je šel Grün še dlje in je v pismu slovenskemu renegatu Dragotinu Dežmanu (1821-1889), ki je medtem svoje ime spremenil v Karl Deschmann, zapisal, da je slovensko narodno gibanje čista burleska (PIVEC STELÈ, Melitta: Pisma Antona Auersperga Karlu Dežmanu. Glasnik Muzejskega društva za Slovenijo 11, 1930, št. 1-4, s. 43-71, tu s. 64).

40 MILADINOVIĆ ZALAZNIK, Mira: Pisma Leopolda Kordescha Anastaziju Grünu. In: MILADINOVIĆ ZALAZNIK, Mira - GRANDA, Stane: Anton Aleksander grof Auersperg. Op. cit., s. 203-225.

41 O njem je pisal RADICS, Peter von: Der Musensohn im Rollstuhl. In: RADICS, Peter von: Anastasius Grün. Verschollenes und Vergilbtes. Op. cit., s. 157-166.

42 ŽIGON, Tanja: Zgodovinski spomin Kranjske. Življenje in delo Petra Pavla pl. Radicsa (1836-1912). Ljubljana: ZZDS in Znanstvena založba FF, 2009, s. 301-347.

43 PAJK, Milan: Peter Pavel pl. Radics. Ljubljanski zvon 32, 1912, št. 9, s. 567-568.

44 Več o tem ŽIGON, Tanja: Kulturelle Selbstverortung und Identitätsfrage: der Krainer Polyhistor Peter von Radics (1836-1912) zwischen zwei Sprachen und Kulturen. Acta neophilologica 46, 2013, št. 1-2, s. 25-38. 
(1780-1854), c.-kr. cestni komisar, nekdanji nadporočnik v avstrijski vojski proti Napoleonu, nosil plemiški predikat. Najverjetneje je šlo za nižje ogrsko uradniško plemstvo. ${ }^{45}$ Radics je bil poročen s publicistko Hedwig Kaltenbrunner (1845-1919), rodili so se jima štirje otroci, od katerih je eden umrl kot dojenček. Redne službe Radics ni imel nikoli, zato sta se s soprogo preživljala s publicističnim delom, večkrat pa zašla tudi v finančne težave. Prav iz teh jima je ničkolikokrat pomagal prav Anastazij Grün, ki je Radicsu kot mecen omogočil tudi vstop v svet znanosti, raziskovanja in pisanja.

Aprila 1906 je Peter Pavel pl. Radics za ljubljanski mesečnik Laibacher Schulzeitung, namenjen nemškemu učiteljstvu na Kranjskem, objavil svoje spomine na Anastazija Grüna in uvodoma poudaril, da je Kranjska lahko ponosna, da je Grün njene gore list, ${ }^{46}$ v nadaljevanju pa povedal, da je imel priložnost, pesnika in politika osebno spoznati v času svojega poročevalskega ter kasneje raziskovalnega dela, ko je pisal o zgodovini rodbine Auersperg. Dodal je še, da sta se veliko srečevala, pogovarjala in da je med njima prišlo tudi do živahne korespondence. Zagotovo je urednik za pisanje prispevka o Grünu izbral Radicsa tudi zato, ker je pred tem izdal že dve obsežni monografski delii ${ }^{47}$ ter več kot ducat člankov o Grünu. ${ }^{48}$ V obeh biografskih delih o Auerspergu je Radics nanizal vrsto podrobno opisanih dogodkov in lokalnih znamenitosti, povezanih tako z zgodovino Turjaških kakor z življenjem Anastazija Grüna, pri čemer o Grünu vedno govori le v presežnikih, kar skorajda spominja na »katalog kreposti «, ${ }^{49}$ katerih utelešenje naj bi bil Anastazij Grün. Radics izpušča vse neprimerne podrobnosti in tako prikaže Grüna kot junaka, ki ga je potrebno posnemati. Toda ravno zaradi izpostavljanja njegovih dobrih in zanemarjanja slabih lastnosti, Grünova osebnost izgubi vso individualnost ter postane skorajda neverodostojna. ${ }^{50}$ Zakaj je Radics o Grünu pisal tako, lažje razumemo, če pogledamo v zakulisje in ocenimo njegov odnos do grofa Auersperga, od čigar velikodušnosti je bil vsaj v šestdesetih letih 19. stoletja, ko si je utiral pot med kranjske ustvarjalce, (finančno) odvisen.

\section{Radics in njegova korespondenca z Grünom}

Radics je višje gimnazijske razrede obiskoval v Gradcu, kjer je leta 1854 maturiral ter se vpisal na tamkajšnjo filozofsko fakulteto. Ker je v tem času prijateljeval z Leopoldom von Sacher-Masochom (1836-1895), ga je ta velikokrat povabil k sebi domov. Vitez von

45 Za podatke se zahvaljujem dr. Mihi Preinfalku. Daljši sestavek o rodbini Radics, ki ga pripravlja, bo predvidoma izšel še letos v knjigi Plemiške rodbine na Slovenskem: 18. stoletje, 2. del (Od Del Negrov do Tegetthoffov).

46 RADICS, Peter von: Erinnerungen an Anastasius Grün. Anastasius-Grün-Nummer der Laibacher Schulzeitung 34, 1906, Sondernummer, s. 93-97, tu s. 93.

47 Leta 1876 so v Stuttgartu ob pesnikovem sedemdesetem rojstnem dnevu natisnili jubilejno monografijo z naslovom Anastasius Grün und seine Heimath, tej pa je dve leti kasneje sledila monografija o Grünovem življenju in delu Anastasius Grün. Verschollenes und Vergilbtes aus dessen Leben und Wirken.

48 Prim. Radicsevo bibliografijo v ŽIGON, Tanja: Zgodovinski spomin Kranjske. Op. cit., s. 301-350.

49 ŠLIBAR, Neva: 'Du, Freiheitspaganini . Biographisches von und über Anastasius Grün. In: JANKO. Anton SCHWOB, Anton: Anastasius Grün und die politische Dichtung. Op. cit., s. 39-54.

Ibidem, s. 41. 
Sacher-Masoch, oče Radicsevega prijatelja, je bil tedaj dvorni svetnik ter policijski nadzornik v Gradcu in je pogosto prirejal družabne večere. Enega od teh so se v zimski salonski sezoni 1857/58 udeležili študenti, ki so uprizorili Goethejevo enodejanko Die Geschwister. ${ }^{51}$ Predstavi je prisostvoval tudi grof Auersperg in srečanje se je Radicsu vtisnilo v spomin. A ne samo njemu, vtis je pustilo tudi pri Anastaziju Grünu, ki je Radicsa še mnogo kasneje rad spomnil na to, da je avtorja >dunajskih sprehodov< srečal prav v hiši policijskega nadzornika. ${ }^{52}$

Radics je v šestdesetih letih 19. stoletja po svojih prvih objavah v glasilu kranjskega zgodovinskega društva Mittheilungen des historischen Vereines für Krain ter v Blätter aus Krain, literarni prilogi časnika Laibacher Zeitung, začel zbirati gradivo o Herbardu VIII. Turjaškem (1528-1575). V času nastajanja te raziskave, ki do danes velja za najpopolnejše delo o junaku iz 16. stoletja, ki je padel v vojni proti Turkom leta 1575, je Radics prvič pisal grofu Auerspergu. ${ }^{53}$ Prosil ga je za dovoljenje, da mu sme posvetiti načrtovano delo. Konec oktobra 1860 se mu je Grün zahvalil za prijazno pismo ter dodal, da je pisanje biografije o Herbardu Turjaškem naloga, vredna zgodovinarja, ki se ukvarja z domoznanstvom, poleg tega pa je izrazil tudi veselje, da bo njegovo ime povezano s tem veliko obetajočim projektom. ${ }^{54}$ Novembra 1860 je Anastazij Grün Radicsu v daljšem pismu zagotovil tudi, da se sme vedno obrniti nanj in da mu bo skušal po svojih skromnih močeh pomagati. ${ }^{55}$ Kmalu zatem mu je Radics pisal, da bi rad začel s pregledovanjem gradiva v dunajskem arhivu (Haus-, Hof- und Staatsarchiv), vendar za to potrebuje dovoljenje. Zavedal se je, da mu Grünova osebna poznanstva in priporočila lahko odprejo marsikatera vrata. V drugi polovici novembra 1860 mu je Auersperg odgovoril, da bo govoril z Alfredom Arnethom (1819-1897), namestnikom direktorja arhiva, poleg tega pa je Radicsu obljubil, da mu lahko napiše tudi dodatno priporočilo. ${ }^{56}$ Tako je Radics dobil dostop do arhivskega gradiva. Monografija o Herbardu Turjaškem je izšla leta 1862 pri založbi dunajskega dvornega knjigarnarja Wilhelma Braumüllerja. ${ }^{57} \mathrm{~S}$ tem delom je Radicsu uspel veliki met. Čeprav je honorar, ki ga je prejel, prinesel manjše razočaranje, saj mu je Braumüller odštel le 60 goldinarjev, ${ }^{58}$ se je mladi avtor upravičeno lahko veselil odziva kritikov. V obširni recenziji, ki je v Blätter aus Krain izšla v treh nadaljevanjih, ${ }^{59}$ ga je neznani avtor, podpisan $\mathrm{z} »-\mathrm{e} «$, poimenoval »der junge Erforscher krainischer

51 RADICS, Peter von: Erinnerungen an Anastasius Grün. Op. cit., s. 93.

52 Ibidem.

53 HHStA, Radicsevo pismo Grünu z dne 27. 10. 1860.

54 RADICS, Peter von: Anastasius Grün. Verschollenes und Vergilbtes. Op. cit., s. 193 (pismo Grüna Radicsu $\mathrm{z}$ dne 30. 10. 1860).

55 Ibidem, s. 194 (Grünovo pismo Radicsu z dne 15. 11. 1860).

56 Ibidem, s. 195 (Grünovo pismo Radicsu z dne 22. 11. 1860).

57 RADICS, Peter von: Herbard VIII., Freiherr zu Auersperg, ein krainischer Held und Staatsmann 1528-1575. Wien: Wilhelm Braumüller, 1862.

58 ZAL, LJU 346, rokopisni elaborati, šk. 2, snopič 37, rokopis Vladislava Fabjančiča, s. 7.

59 »-e.«: Literatur. Blätter aus Krain 13 (1862), s. 52. 
Geschichte $«,{ }^{60}$ torej mladi raziskovalec kranjske zgodovine, in hvalil njegovo delo, napisano na podlagi do tedaj nepoznanih arhivskih virov.

Konec zimskega semestra 1861/62 je Radics zašel v hude finančne težave. Od jeseni leta 1858 je kot suplent na ljubljanski gimnaziji poučeval nemščino, zgodovino in zemljepis. Ker pa ni imel univerzitetne diplome, saj študija zaradi bolezni nikoli ni zaključil, je marca 1862 ostal brez dela in s tem brez stalnih prihodkov. Poleg tega je bil sredi pisanja treh daljših znanstvenih razprav. Ukvarjal se je zgodovino Kranjske, ki je leta 1862 izšla pri ljubljanskem založniku Giontiniju, zbiral je gradivo o Primožu Trubarju ter pripravljal članek o zgodovini stiškega samostana. ${ }^{61}$ Ker je moral obenem skrbeti tudi za ostarelo mater, mu ni preostalo drugega, kot da piše Anastaziju Grünu. V šest strani dolgem pismu je tarnal zaradi izgube službe ter ga prosil za nasvet in pomoč. Čeprav Grünova pisma Radicsu niso ohranjena, smemo domnevati, da Auersperg rojaku glede novega delovnega mesta v Ljubljani ni mogel pomagati.

Spomladi leta 1862 je Radics zapustil Ljubljano in odšel na Dunaj. Začel je obiskovati predavanja iz paleografije pri profesorju Theodorju von Sicklu (1826-1908), ${ }^{62}$ ki so jim smeli prisostvovati tudi zunanji interesenti, a le, če je prostor to dovoljeval. ${ }^{63}$ Pri Sicklu si je Radics nabral izkušenj in dragocenega znanja o starih pisavah, kar mu je pri kasnejših raziskavah zelo koristilo.

Toda Radics je moral čim prej priti do rednega zaslužka. 15. 7. 1862 je zaprosil za mesto pripravnika v dunajskem državnem arhivu, a žal ni imel sreče. ${ }^{64}$ Obrnil se je na Grüna in ga prosil, naj se zavzame zanj pri ministru grofu Rechbergu (1806-1899), saj se bo, tako mu je pisal, le tako uresničila njegova največja želja, da bi delal na raziskovalnem področju. Grün je prošnji ustregel in konec julija 1862 je minister Radicsa osebno sprejel. Še isti večer se je Radics zahvalil Grünu, ${ }^{65}$ a tedaj še ni slutil, da obisk pri ministru ne bo obrodil sadov; dela v državnem arhivu nikoli ni dobil. Zadovoljiti se je moral s priložnostnim pisanjem za različne časnike, s čimer je zaslužil komaj dovolj za preživetje. Iz težav mu je ponovno pomagal Grün. Radics si je namreč želel raziskati jezikovne, zgodovinske in topografske značilnosti Kočevske. Grün ga je zato poleti 1862 priporočil vplivnemu knezu Karlu Viljemu (Carlosu) Auerspergu (1814-1890), četrtemu vojvodi Kočevskemu, od leta 1861 predsedniku gosposke zbornice, ki je bil obenem tudi cesarski, kraljevi in tajni svetnik. Ker je knez je pokazal zanimanje za omenjene raziskave, se je Radics konec poletja 1862 odpravil v Kočevje in leta 1864 svoje izsledke objavil v daljši razpravi v reviji Österreichische Revue. ${ }^{66}$

60 Ibidem.

61 KFU, zapuščina Anastazija Grüna (Radicsevo pismo Grünu z dne 5. 2. 1862).

62 STESKA,Viktor: Peter Pavel pl. Radics. Carniola 3/4 (1912), s. 293-296, tu s. 294.

63 Theodor von Sickel je bil eden prvih profesorjev na leta 1854 ustanovljenem Inštitutu za avstrijsko zgodovinsko raziskovanje (Institut für Österreichische Geschichtsforschung). Bil je s Saškega, saj je tudi na področju raziskovanja zgodovinskih virov, paleografije in diplomatike še primanjkovalo domačih strokovnjakov (WINKELBAUER, Thomas: Das Fach Geschichte an der Wiener Universität. Wien: V\&R unipress, 2018, s. 96-110).

64 NMS, Radicseva zapuščina, TE 6 / I / 1 / 4t, odgovor Ministrstva za zunanje zadeve z dne 15. 7. 1862.

65 HHStA, Radicsevo pismo Grünu z dne 29. 7. 1862.

66 RADICS, Peter von: Die altdeutsche Colonie Gottschee in Krain. Österreichische Revue 2/3 (1864), s. 210221; $2 / 4$ (1864), s. 210-231. 
Ko je Radics zaključeval z raziskovalnim delom na Kočevskem, se je vedno bolj zavedal, da se spet bližajo negotovi meseci brez prihodkov. Ker je upal, da bo kmalu dobil delo v Ljubljani, se je začel ukvarjati z raziskovanjem ljubljanske licejske knjižnice, vendar je moral delo konec leta 1862 zaradi nepričakovane materine bolezni prekiniti in se nemudoma vrniti k njej na Dunaj. Nenačrtovani izdatki so ga močno udarili po žepu, ${ }^{67}$ zato je decembra Grünu poročal o težavah, ki so se mu pripetile, in ga prosil, naj mu pomaga iz denarne zagate, saj se sicer ne more vrniti v Ljubljano in nadaljevati arhivskega dela. Prosil ga je, naj mu pošlje 50 goldinarjev, ki mu bodo omogočili dvomesečno bivanje v Ljubljani. ${ }^{68}$

Leta 1863 je Radics tako v Ljubljani kot tudi drugod veliko raziskoval na področju starih tiskov. Zadrževal se je v štajerskem samostanu Rein, ki velja za najstarejši cistercijanski samostan na svetu, bil pa je tudi v Zagrebu, kjer je našel prodano Valvasorjevo knjižnico. Takoj zatem je, navdušen nad svojim odkritjem, pisal Grünu, da gre za izredno pomembno najdbo, ki dopolnjuje njegovo delo o baronu Valvasorju, ki ga pripravlja že nekaj let. ${ }^{69}$ Grün je bil navdušen, s svojimi zvezami je pomagal Radicsu, da je dobil prost dostop do gradiva, ta pa mu je v pismih stalno poročal o napredku raziskav ${ }^{70}$ in mu zagotavljal, da bo nekoč izdal obsežno monografijo o Valvasorju. Poročal je tudi, da je polno zaposlen, saj pripravlja študijo o stiškem samostanu, poleg tega pa nadaljuje s pisanjem razprav o različnih vrstah rokopisov, ki jih hranijo samostani v Notranji Avstriji. ${ }^{71}$ Že leta 1863 je imel pripravljen rokopis z naslovom Die k. k. öffentliche Studienbibliothek in Laibach, ki je vseboval poglavja o samostanskih knjižnicah na Kranjskem, o ljubljanski knežji fidejkomisni in zagrebški Valvasorjevi knjižnici. Zaradi vseh naštetih raziskav je upal, da bo v Ljubljani brez težav dobil mesto bibliotekarja, za katero se je nameraval potegovati oktobra $1863 .{ }^{72}$ Za vsak slučaj je junija 1863 Anastaziju Grünu poslal daljše pismo, kjer je obelodanil svoje načrte ter ga prosil, naj zanj glede tega mesta posreduje pri vplivnih ljudeh v Ljubljani. ${ }^{73}$ Žal pa so šli dogodki svojo pot. Junija 1865 je v Ljubljano iz Lvova prišel Gottfried Muys $(1828-1898)^{74}$ in prevzel mesto vodje knjižnice. ${ }^{75}$ Radics je ponovno ostal brez dela.

Konec istega leta je Radics svojo srečo ponovno poskusil na Dunaju. Šestega novembra 1863 je na dunajsko dvorno knjižnico naslovil prošnjo za delovno mesto pomočnika

67 KFU, zapuščina Anastazija Grüna (Radicsevo pismo Grünu z dne 27. 12. 1862).

68 Ibidem.

69 KFU, zapuščina Anastazija Grüna (Radicsevo pismo Grünu z dne 28. 2. 1863).

70 KFU, zapuščina Anastazija Grüna (Radicseva pisma Grünu z dne 2. 3. 1863; 20. 4. 1863; 15.5 .1863 ; 4. 6. 1863; prim. tudi RADICS, Peter von: Anastasius Grün. Verschollenes und Vergilbtes Op. cit., s. 198-199 (Grünovo pismo Radicsu z dne 26. 4. 1863).

71 KFU, zapuščina Anastazija Grüna (Radicsevo pismo Grünu z dne 28. 2. 1863).

72 KFU, zapuščina Anastazija Grüna (Radicsevo pismo Grünu z dne 27. 12. 1862).

73 KFU, zapuščina Anastazija Grüna (Radicsevi pismi Grünu z dne 28. 6. 1863 in z dne 26. 10. 1863).

74 PIRJEVEC, Avgust (ur.): Levstikova pisma. Ljubljana: Slovenska matica, 1931, s. 202-205.

75 Podoben scenarij se je odigral tudi poleti 1872. Julija se je namreč upokojil Ludvik Germonik (1823-1909) ter odstopil z mesta skriptorja ljubljanske licejske knjižnice in zdelo se je, da bo Radics končno prišel do zaposlitve, ki si jo je želel. Vodja knjižnice Gottfried Muys je o prostem mestu nemudoma obvestil Levstika (PIRJEVEC, Avgust (ur.): Levstikova pisma. Op. cit., s. 206). Ta si je službo želel, a se je najbolj bal prav Radicseve konkurence. Vedel je, da slednji uživa podporo Auerspergov, zaradi katere bi utegnil brez težav dobiti delo. Dne 17. 8. 1872 je Levstik zaskrbljen pisal Muysu, tožil o Radicsu in ga imenoval »der kleine Peter« (ibidem, s. 212). A strah je bil zaman, saj dela tudi tokrat ni dobil Radics, temveč Levstik. 
z letno plačo 525 fl. avstrijske veljave. ${ }^{76}$ Zaradi priporočil Anastazija Grüna se je zanj zavzel Eligius Franz Josef von Münch-Bellinghausen (1806-1871) ${ }^{77}$ kot dramatik, pesnik in pripovednik bolj znan pod psevdonimom Friedrich Halm. Ta je bil leta 1844 imenovan za dvornega svetnika in prvega kustosa dvorne knjižnice. A Halm konec leta 1863 ni bil več popolnoma prepričan, da je Radics pravi kandidat. Na silvestrski večer leta 1863 je Radics zato prosil Grüna, naj ga še enkrat priporoči. ${ }^{78}$ Grof Auersperg je sicer posredoval, a januarski odgovor dvorne knjižnice, ki ga je podpisal drugi kustos, Friedrich von Bartsch (1798-1873), je prinesel razočaranje. ${ }^{79} \mathrm{Ni}$ izključeno, da je proti Radicsu tedaj nastopil ugledni in cenjeni član dunajske akademije znanosti Fran Miklošič (1813-1891), do leta 1862 skriptor v dvorni knjižnici, ki je Radicsa konec petdesetih let spoznal kot skrajno neresnega kandidata, ki je nenehno prestavljal učiteljski izpit, na koncu pa k njemu sploh ni pristopil. ${ }^{80}$

Sredi leta 1864 srečamo Radicsa v Zagrebu, kjer je za nekaj mesecev prevzel uredništvo dnevnika Agramer Zeitung, že konec leta pa so ga slovenski prvaki z Bleiweisom in Costo na čelu povabili v Ljubljano in mu zaupali urejanje časnika za domovinske interese v nemškem jeziku, ki je imel naslov Triglav. ${ }^{81}$ Urejal ga je do aprila 1866, nakar se je odločil, da kot vojni poročevalec odide na italijansko bojišče, po končani vojni pa se je vrnil na Dunaj. V tem obdobju je Grünu napisal svoje zadnje pismo, ki je ohranjeno v graški zapuščini. Dne 14. januarja 1868 mu je poročal, da je odkril dramo iz 17. stoletja z naslovom Der Hl. Eusthachius (Sv. Evstahij), ${ }^{82}$ ki je posvečena deželnemu glavarju iz rodu Turjaških, Volfu Engelbertu (1610-1673) in so jo igrali v turjaški palači v Ljubljani pred dvesto leti. ${ }^{83}$ Obenem je pisal, da pripravlja biografijo cesarskega in kraljevega tajnega svetnika ter vrhovnega komornika kneza Vincenca Karla Auersperga (1812-1867) iz mlajše veje knežje linije, t. i. češko-tirolske linije, ki je bil od leta 1863 tudi vrhovni direktor dvornega gledališča ${ }^{84}$ Grüna je prosil, naj mu posreduje podatke o knezu, pisma ali zapiske, ki bi osvetlili njegovo osebnost, življenje in delo. ${ }^{85}$ Danes ni več ugotovljivo, ali je Grün Radicsevi prošnji ustregel, prav tako ni znana Radicseva objava o knezu Vincencu Karlu. ${ }^{86}$

76 NMS, Radicseva zapuščina, TE 6 / I / 1, zap. št. 4u.

77 HHStA, Radicsevo pismo Grünu z dne 31. 12. 1863.

78 Ibidem.

79 NMS, Radicseva zapuščina, TE 6 / I / 1, zap. št. 4u.

80 NMS, Radicseva zapuščina, TE 6 / I / 1, zap. št. 4 s.

81 Več o tem ŽIGON, Tanja: Nemški časnik za slovenske interese - Triglav (1865-1870). Ljubljana: ZZDS, 2004, s. 81-83 in 120-121. Zadnji Triglavov urednik je bil v letih 1869 in 1870 slovenski pisatelj, dramatik in satirik Jakob Alešovec (prim. ŽIGON, Tanja: Übersetzung oder Adaption: Fallbeispiel Jakob Alešovec (1842-1901). Acta neophilologica 50, 2017, št. 1-2, s. 153-171).

82 Besedilo je objavil v podlistku dnevnika Österreichischer Volksfreund. Prvo nadaljevanje je izšlo v št. 92 (20. 4. 1867).

83 KFU, zapuščina Anastazija Grüna (Radicsevo pismo Grünu z dne 18. 1. 1868).

84 Knez Auersperg je Radicsa na Dunaju vabil v gledališče in mu dovolil zasesti svojo ložo, kadar ni bilo veliko obiska (prim. ZAL, LJU 346, rokopisni elaborati, šk. 2, snopič 37, rokopis Vladislava Fabjančiča, s. 16). KFU, zapuščina Anastazija Grüna (Radicsevo pismo Grünu z dne 18. 1. 1868). NMS, Radicseva zapuščina, TE 1 / II / d, zap. št. 4 (zbrano rokopisno gradivo). 
V sedemdesetih letih 19. stoletja je bil Radics na Dunaju sodelavec nekaterih časnikov, med drugim je od leta 1872 do leta 1873 urejal časopis Die Regentenhalle, namenjen visoki družbi, od leta 1871 do leta 1873 pa tudi razvedrilni list Wiener Salonblatt. Leta 1872 so se izdajatelji Salonblatta odločili, da bodo izdajali letno prilogo lista, imenovano Wiener Salon-Album. Urejal jo je Radics. Album je bil družinski list, ki je nadaljeval tradicijo tovrstnih publikacij, namenjenih kratkočasnemu branju za staro in mlado iz sredine 19. stoletja. Med avtorji, ki so objavljali v Radicsevem dunajskem Albumu, ni zvenečih imen, kakršna so se na primer znašla v podobni publikaciji v Trstu (Illustriertes Familienbuch).$^{87}$ Veliko prispevkov je podpisal kar Radics sam, sledili so znanci in njegovo sorodstvo. Objavljal je članke svoje soproge Hedwig pl. Radics-Kaltenbrunner, pesmi njenega dedka Mathiasa Leopolda Schleiferja (1771-1842), prispevke svojega znanca iz Zagreba Heinricha Moritza Penna (1838-1919) itd. Med avtorji, ki so objavljali tudi v tržaškem listu, zasledimo le Roberta Hamerlinga (1830-1889). Jeseni 1871 se je Radics trudil, da bi za sodelovanje navdušil Anastazija Grüna, saj si je obetal, da bo tako privabil več bralstva. Oktobra mu je pisal in ga prosil, naj mu čim prej pošlje svoje prispevke..$^{88}$ Toda Grün na uradni dopis uredništva časopisa Wiener Salon-Album, ki ga je podpisal Radics kot odgovorni urednik, ni odgovoril. Tako v Albumu zaman iščemo njegove objave. Zakaj se povabilu za sodelovanje ni odzval, lahko le ugibamo. A tudi Salon-Album se ni dolgo obdržal na trgu. Za božič leta 1873 je izšla druga in s tem zadnja številka drugega letnika.

\section{Sklep}

Peter Pavel pl. Radics je bil Anastaziju Grünu hvaležen. Grof Auersperg je bil njegov mecen in dobrotnik. Podpiral je Radicseve domoznanske raziskave, razumel je njegovo znanstveno in raziskovalno delo, mu pri tem svetoval ter pri znancih zastavljal svojo besedo zanj. Poleg tega pa se je Radics nanj lahko zanesel v težkih trenutkih v šestdesetih letih, ko mu je Grün vedno znova pomagal iz finančnih zagat. Prav zaradi tega so Radicseva besedila o Turjaških, še posebej o Anastaziju Grünu, pogosto podobna slavospevom.

Leta 1876, ko je Grün praznoval svoj sedemdeseti rojstni dan, je Radics objavil prvo monografijo o njem, delo z naslovom Anastasius Grün und seine Heimath. Auersperg se je Radicsevega rojstnodnevnega darila razveselil in se mu je zanj zahvalil v kratkem pismu. ${ }^{89}$ Septembra 1876 je Grün umrl. Omenjeno pismo je zadnje doslej znano, ki ga je poslal svojemu kranjskemu rojaku.

Za Radicsa je bil prijateljski odnos z Grünom nujnost, saj si je le z njegovo pomočjo lahko zagotovil nemoteno raziskovalno delo predvsem v šestdesetih letih 19. stoletja. Obratno pa je bil Radics za Grüna mlad in obetajoč kranjski historiograf, ki ga je cenil

87 ŽIGON, Tanja - KRAMBERGER, Petra: Nemško časopisje v Trstu v 18. in 19. stoletju. Kronika (Iz zgodovine Trsta) 67, 2019, št. 3, s. 513-530, tu s. 522.

88 HHStA, Radicsevo pismo Grünu z dne 1. 10. 1871.

89 RADICS, Peter von: Anastasius Grün. Verschollenes und Vergilbtes. Op. cit., s. 199-200 (Grünovo pismo Radicsu z dne 21. 4. 1876). 
in ga zato tudi finančno podpiral pri njegovem delu. Prav zato smemo Anastazija Grüna, ki ni bil mecen le Radicsu, katerega primer smo si ogledali, ocenjevati tudi v povsem drugi luči, in sicer kot ljubitelja kulture, umetnosti, raziskovanja in znanstvenih dosežkov svojih rojakov. Četudi se zdi, da je na političnem parketu včasih zastopal drugačna stališča in je na slovenski jezik in kulturo gledal precej paternalistično, pa je bil mnogokrat pripravljen prisluhniti in, kot smo videli, tudi finančno podpreti prizadevanja rojakov iz kranjskega mikrokozmosa, iz katerega je tudi sam izhajal.

\section{Viri in literatura}

AS, Arhiv Republike Slovenije, AS 984, Peter pl. Radics.

KFU, Karlova in Francova univerza v Gradcu, Oddelek za germanistiko, zapuščina Anastazija Grüna.

HHStA, Wiener Haus-, Hof- und Staatsarchiv (Hišni, dvorni in državni arhiv na Dunaju), Fürstlich Auerspergsches Archiv, razdelek XXI (Thurn am Hart), C. 49, karton 30.

NMS, Narodni muzej Slovenije, Radicseva zapuščina.

ZAL, Zgodovinski arhiv Ljubljana, ZAL LJU 346, rokopisni elaborati, šk. 2, snopič 37, rokopis Vladislava Fabjančiča.

CASTLE, Eduard (ur.): Anastasius Grüns Werke in sechs Teilen. Berlin - Leipzig - Wien - Stuttgart: Deutsches Verlagshaus Bong \& Co., 1909. VI. del.

BIRK, Matjaž: Österreichisch-slowenischer Kulturtransfer am Beispiel von Anastasius Grün und France Prešeren. Modern Austrian Literature 41, 2008, št. 2, s. 1-18.

GRANDA, Stane: Anastazij Grün - gospodarstvenik. In: MILADINOVIĆ ZALAZNIK, Mira - GRANDA, Stane (ur.): Anton Aleksander grof Auersperg - Anastazij Grün. Ljubljana: Nova revija, 2009, s. 31-45.

GRDINA Igor: Anton Aleksander Auersperg ter slovenska in nemška (literarno)zgodovinska stvarnost. In: MILADINOVIĆ ZALAZNIK, Mira - GRANDA, Stane (ur.): Anton Aleksander grof Auersperg - Anastazij Grün. Ljubljana: Nova revija, 2009, s. 47-65.

GRDINA, Igor: Anastazij Zelenec ter slovenska in nemška (literarno)zgodovinska stvarnost. In: GRDINA, Igor (ur.): Med dolžnostjo spomina in razkošjem pozabe: kulturnozgodovinske študije. Ljubljana: Založba ZRC, ZRC SAZU, 2006, s. 241-256.

JANKO, Anton - SCHWOB, Anton (ur.): Anastasius Grün und die politische Dichtung des Vormärz. München: Südostdeutsches Kulturwerk, 1995.

JANKO, Anton: Anastasius Grün als Übersetzer von Volksliedern. In: KONDRIČ HORVAT, Vesna (ur.): Nekoč se bodo vendarle morale sesuti okostenele pregrade med ljudstvi: spominski zbornik ob sedemdesetletnici Draga Graha. Ljubljana: ZZFF in Oddelek za germanistiko z nederlandistiko in skandinavistiko, 2007, s. 56-68.

JAVOR BRIŠKI, Marija: The uses of the past: Anastasius Grün's political ideas in the field of fiction. XLinguae 8, 2015, št. 3, s. 31-40.

KRAUSSE, Erika (ur.): Der Brief als wissenschaftshistorische Quelle, Berlin: VWB-Verlag, 2005. 
KORDESCH, Leopold: Märzveilchen. Illyrisches Blatt. Zeitschrift für Vaterland, Kunst, Wissenschaft und geselliges Leben 20, 1848, št. 27, s. 105.

MÁDL, Antal: Anastasius Grün und Nikolaus Lenau. Eine Dichterfreundschaft. In: JANKO, Anton SCHWOB, Anton (ur.): Anastasius Grün und die politische Dichtung des Vormärz. München: Südostdeutsches Kulturwerk, 1995, s. 55-80.

MELIK, Vasilij: A. A. Auersperg in slovenski narod. Zgodovinski časopis 41, 1987, št. 2, s. 285-295.

MELIK, Vasilij: Alexander graf Auersperg und die Slowenen. In: JANKO, Anton - SCHWOB, Anton (ur.): Anastasius Grün und die politische Dichtung des Vormärz. München: Südostdeutsches Kulturwerk, 1995, s. 93-108.

MILADINOVIĆ ZALAZNIK, Mira: Deutsch-slowenische literarische Wechselbeziehungen. Leopold Kordesch und seine Zeit. Ljubljana: ZZFF, Oddelek za germanistiko s skandinavistiko in nederlandistiko, 2008.

MILADINOVIĆ ZALAZNIK, Mira: Anastasius Grün und das Vereinte Slowenien. Germanistische Mitteilungen 67, 2008, s. 51-63.

MILADINOVIĆ ZALAZNIK, Mira - GRANDA, Stane (ur.): Anton Aleksander grof Auersperg - Anastazij Grün. Ljubljana: Nova revija, 2009.

MILADINOVIĆ ZALAZNIK, Mira: Pisma Leopolda Kordescha Anastaziju Grünu. In: MILADINOVIĆ ZALAZNIK, Mira - GRANDA, Stane (ur.): Anton Aleksander grof Auersperg - Anastazij Grün. Ljubljana: Nova revija, 2009, s. 203-225.

MILADINOVIĆ ZALAZNIK, Mira: Auersperg, Marija Anton Aleksander, grof (1806-1876). In: ŠTRBENC SVETINA, Barbara et al. (ur.): Slovenska biografija. Ljubljana: SAZU in ZRC SAZU, 2013 (dostopno na: http://www.slovenska-biografija.si/oseba/sbi131820/\#novi-slovenski-biografski-leksikon; dostop 10. 9. 2019).

PAJK, Milan: Peter Pavel pl. Radics. Ljubljanski zvon 32, 1912, št. 9, s. 567-568.

PIRJEVEC, Avgust (ur.): Levstikova pisma. Ljubljana: Slovenska matica, 1931.

PIVEC STELÈ, Melitta: Pisma Antona Auersperga Karlu Dežmanu. Glasnik Muzejskega društva za Slovenijo 11, 1930, št. 1-4, s. 43-71.

POŽAR, Breda: Anastasius Grün in Slovenci. Maribor: Založba Obzorja, 1970.

PREINFALK, Miha: Auerspergi. Po sledeh mogočnega tura. Ljubljana: Zgodovinski inštitut Milka Kosa ZRC SAZU, 2005.

RADICS, Peter von: Herbard VIII., Freiherr zu Auersperg, ein krainischer Held und Staatsmann 15281575. Wien: Wilhelm Braumüller, 1862.

RADICS, Peter von: Die altdeutsche Colonie Gottschee in Krain. Österreichische Revue 2/3 (1864), s. 210-221; 2/4 (1864), s. 210-231.

RADICS, Peter von: Anastasius Grün und seine Heimath. Festschrift zum 70jährigen Jubiläum des Dichters (11. April 1876). Stuttgart: Verlag der J. G. Cotta'schen Buchhandlung, 1876.

RADICS, Peter von: Anastasius Grün. Verschollenes und Vergilbtes aus dessen Leben und Wirken. Leipzig: Verlag von Hermann Foltz, 1879.

RADICS, Peter von: Der Musensohn im Rollstuhl. In: RADICS, Peter von: Anastasius Grün. Verschollenes und Vergilbtes aus dessen Leben und Wirken. Leipzig: Verlag von Hermann Foltz, 1879 , s. $157-166$.

RADICS, Peter von: Anastasius Grüns Lehrer und Freund der slovenische Dichter France Preschiren als deutscher Poet. Leipzig: J. H. Webel, 1882. 
RADICS, Peter von: Erinnerungen an Anastasius Grün. Anastasius-Grün-Nummer der Laibacher Schulzeitung 34, 1906, Sondernummer, s. 93-97.

SCHARMITZER, Dietmar: Anastasius Grün (1806-1876). Leben und Werk. Wien - Köln - Weimar: Böhlau, 2010.

SERNETZ, Peter: Anastasius Grün als Übersetzer slovenischer Volsklieder. Doktorska disertacija. Graz: Universität Graz, 1932.

STESKA,Viktor: Peter Pavel pl. Radics. Carniola 3/4, 1912, s. 293-296.

SEUME, Gottfried: Spaziergang nach Syrakus im Jahre 1802. München: DTV, 1985.

SIENERTH, Stefan: Anastasius-Grün-Rezeption und der Standort der siebenbürgisch-deutschen Lyrik in der ersten Hälfte des 19. Jahrhunderts. In: JANKO, Anton - SCHWOB, Anton (ur.): Anastasius Grün und die politische Dichtung des Vormärz. München: Südostdeutsches Kulturwerk, 1995, s. $123-136$.

ŠLIBAR, Neva: ‘Du, Freiheitspaganini . Biographisches von und über Anastasius Grün. In: JANKO, Anton - SCHWOB, Anton (ur.): Anastasius Grün und die politische Dichtung des Vormärz. München: Südostdeutsches Kulturwerk, 1995, s. 39-54.

TRDINA, Janez: Avtobigrafska pisma (ur. Fr. Derganc). Ljubljanski zvon 26, 1906, št. 2, s. 77-82.

WINKELBAUER, Thomas: Das Fach Geschichte an der Wiener Universität. Wien: V\&R unipress, 2018.

ŽIGON, Tanja: Nemški časnik za slovenske interese - Triglav (1865-1870). Ljubljana: ZZDS, 2004.

ŽIGON, Tanja: Zgodovinski spomin Kranjske. Življenje in delo Petra Pavla pl. Radicsa (1836-1912).

Ljubljana: ZZDS, 2009.

ŽIGON, Tanja: Kulturelle Selbstverortung und Identitätsfrage: der Krainer Polyhistor Peter von Radics (1836-1912) zwischen zwei Sprachen und Kulturen. Acta neophilologica 46, 2013, št. 1-2, s. 25-38.

ŽIGON, Tanja. Übersetzung oder Adaption: Fallbeispiel Jakob Alešovec (1842-1901). Acta neophilologica 50, 2017, št. 1-2, s. 153-171.

ŽIGON, Tanja - KRAMBERGER, Petra: Nemško časopisje v Trstu v 18. in 19. stoletju. Kronika (Iz zgodovine Trsta) 67, 2019, št. 3, s. 513-530.

izred. prof. dr. Tanja Žigon, PhD

Oddelek za prevajalstvo

Filozofska fakulteta, Univerza v Ljubljani

Aškerčeva cesta 2, SI-1000 Ljubljana, Slovinsko

tanja.zigon@ff.uni-lj.si 